\title{
Influence of soil moisture regime on the species diversity and biomass of the herb layer of pine forests in the Ural Mountains
}

\author{
Natalya Sergeevna Ivanova ${ }^{1,2}$, Ekaterina Sergeevna Zolotova ${ }^{3 *}$, Guoqing $\mathbf{L i}^{4,5}$ \\ ${ }^{1}$ Botanical Garden of the Ural Branch of the Russian Academy of Sciences, 202a March 8 street, \\ Yekaterinburg, Russia, 620144 \\ ${ }^{2}$ Ural State Forest Engineering University, 37 Sibirsky Trakt street, Yekaterinburg, Russia, 620100 \\ ${ }^{3}$ A.N. Zavaritsky Institute of Geology and Geochemistry, Ural Branch of Russian Academy of Sciences, \\ 15 Akad. Vonsovsky street, Yekaterinburg, Russia, 620016 \\ ${ }^{4}$ Institute of Soil and Water Conservation, Chinese Academy of Sciences and Ministry of Water Resources, \\ Yangling 712100, China \\ ${ }^{5}$ State Key Laboratory of Soil Erosion and Dryland Farming on the Loess Plateau, \\ Northwest A\&F University, Yangling 712100, China \\ *e-mail corresponding author: afalinakate@gmail.com
}

Received: 5 May 2020 / Accepted: 16 October 2020

\begin{abstract}
Adaptation of plant communities is an important factor for maintaining their functioning and stability in changing conditions. The aim of our research is study of the effect of soil moisture regime on the species richness and biomass of the herb layer for old-growth coniferous forests in the Ural Mountains (Russia). The research has been carried out between $57^{\circ} 00^{\prime} \mathrm{N} ; 60^{\circ} 15^{\prime \prime} \mathrm{E}$ and $57^{\circ} 05^{\prime} \mathrm{N} ; 60^{\circ} 25^{\prime} \mathrm{E}$. The studied area is part of the Zauralsky hilly piedmont province, the Southern boreal forest region. Sample plots $(0.25$ hectares) were laid in pine forests growing in habitats with different moisture regimes: insufficient, optimal (stable), and excessive. The research was conducted in 2010. To determine the herb layer productivity, 10-20 subplots $1 \mathrm{x} 1 \mathrm{~m}$ in size were laid on each sample plot. Data analysis is based on the One-way ANOVA and species abundance distributions. It has been established that species richness in extreme (insufficient and excessive soil moisture regime (Cowberry pine forest and Pine forest with shrubs and sphagnum) and optimal (stable) soil moisture regime (Multi-herb pine forest) were found to vary significantly, with soil moisture regime being a statistically significant factor. By contrast, herb layer biomass is maintained fairly stable regardless of the soil moisture regimes. ANOVA showed no significant differences between pine forests growing under different soil moisture regimes. It has been found that biomass is maintained by increasing of the dominant species contribution to the overall biomass and increasing of the approximation function graph slope. At the same time, the parameter $\beta$ of exponential and power approximating functions is increased and can be considered as an indicator of influencing on forest ecosystems and a measure of their adaptation to insufficient and excessive soil moisture. Thus, species abundance distributions can be used as method to measure the effects of factors that determine forest ecosystem composition and functioning.
\end{abstract}

Keywords: soil moisture regime, forest type, old-growth coniferous forests, herb layer, species diversity, biomass, Ural Mountains.

\section{Introduction}

Adaptation to habitat features is important for the functioning and sustainability of ecosystems (Maiti et al., 2016; Muller et al., 2019). Therefore, research on this issue is of great importance. However, the number of articles on plant adaptation to external influences was relatively small until 2005. Later, there was an increase in interest in this issue and the number of publications began to grow exponentially (Haunschild et al., 2016; Mengist et al., 2019). 
The urgency of the problem is sharply increasing due to global climate warming, probability of local and global environmental crises, restructuring of the river water regime (Safina \& Golosov, 2018), reduced stability and regulatory functions of ecosystems, reduced stability of agriculture and forestry (Halofsky et al., 2018). Most researchers believe climate change will impact species resistance and occurrence, transform ecosystem biodiversity, structure and functions (Kellomäki, 2016; Murray et al., 2017; Bouchard et al., 2019). The problem is compounded by the widespread an increasing human population and the global consumption patterns growth. As a result, climate change is repeatedly amplified by anthropogenic impacts, and forest degradation is becoming more widespread, leading to the transformation of ecosystem services (Alamgir et al., 2014; Parrotta et al., 2016). It was found that 15 out of 24 recognized ecosystem services are in decline worldwide (Millennium Ecosystem Assessment, 2005). This will certainly affect the well-being of human society (Shaw et al., 2011). Therefore, the relevance and intensity of research on the adaptation possibilities of natural ecosystems increases every year (Galicia \& Zarco-Arista, 2014).

To date, it has been proved that plant resistance to adverse abiotic and biotic factors is ensured by a wide variety of mechanisms functioning at different levels of organization (Bucher et al., 2019; Courbier \& Pierik, 2019). An important role in plant adaptation to various stresses is played by variability of biochemical indicators (Aganina \& Tarkhanov, 2016; Paraskevopulo et al., 2017; Ramakrishna \& Gill, 2018). Changes in intensity of plant uptake of mineral elements are assumed to suggest adaptation to extreme environmental conditions (Habarova et al., 2015; Soares et al., 2019).

The largest number of studies on plant adaptation is related to tree species. Generally, adaptation to one of the factors, the most often temperature (Hänninen, 2016; Montwé et al., 2018), soil moisture occasionally, is studied (Guerin \& Lowe, 2013; Polle et al., 2018). Special attention is paid to tree plant adaptation to urban settings and industrial pollution (Paraskevopulo et al., 2017; Legoshchina et al., 2019). Studies on grass adaptation are given less attention to and their focus is mainly shifted towards agricultural and ornamental crops. A special emphasis can be laid on the studies on herbaceous plant frost resistance (Franklin \& Wigge, 2014; Bucher et al., 2019) and their adaptation to climate warming (Franklin \& Wigge, 2014), as well as to competition for light (Courbier \& Pierik, 2019), soil moisture (Ferreira et al., 2015; Astamirova et al., 2016), and to technogenic pollution (Shimalina et al., 2019). At that investigation of adaptation are often associated with high levels of uncertainty, and different methods show conflicting results, accounting for which are particularly relevant for forecasting and modeling the state and stability of ecosystems (Straub \& Grêt-Regamey, 2006). But predictive models themselves are also quite rare (Landuyt et al., 2013; Kamlun \& Arndt, 2019; Calder et al., 2019). Therefore, we can conclude that, despite the huge number of publications on adaptation, many problems have not been solved yet (Fisher et al., 2009; Hölting et al., 2019). In addition, there are still many unresolved issues. In particular, mechanisms to maintain resistance, species diversity and productivity of ecosystems haven't been clarified, especially when a number of species extinct. Furthermore, studies on ecosystem adaptation are extremely relevant because of the awareness of the importance of their ecosystem functions to humanity (Mumba et al., 2016).

The studies carried out in the mountainous regions have shown that these ecosystems are particularly vulnerable to climate changes; factor impacts are more obvious and intense in this area. In addition, the exceptional importance of mountain ecosystems for climate and water control is recognized (Werners et al., 2016). Studies on these issues are extremely relevant for sustainable biological resources management. Their exceptional role in providing ecosystem services is also noted (Mengist et al., 2019), and the total number of ecosystem services provided by mountain ecosystems is 317 . Therefore, the study of mountain ecosystems is extremely relevant for the sustainable management of biological resources. Despite this, mountain ecosystems have not been sufficiently studied (Mengist et al., 2019).

The aim of our research is study of the effect of soil moisture regime on the species richness and biomass of the herb layer for old-growth coniferous forests in the Ural Mountains (Russia).

\section{Materials and Methods}

\subsection{Study area}

Ural is a mountain region in Russia spreading between the East European and West Siberian plains. It is divided into Southern, Middle, Northern, Nether-Polar and Polar Ural. The Middle Urals is the lowest part of the mountain range. These mountains typically do not exceed 800 meters above sea level. The region is an industrial center and is rich in minerals. The research has been carried out between $57^{\circ}$ $00^{\prime} \mathrm{N} ; 60^{\circ} 15^{\prime \prime} \mathrm{E}$ and $57^{\circ} 05^{\prime} \mathrm{N}$; 60 $60^{\circ}$ 'E (Fig. 1). The studied area is part of the Zauralsky hilly piedmont province, the Southern boreal forest region, based on the Sverdlovsk region forest type cadaster (Kolesnikov et al., 1973). It is a dissected foothill formed by alternating meridian uplands and chains with wide intermountain extended downhills with large lakes surrounded by peat swamps. Elevation is $200-500 \mathrm{~m}$ above sea. The climate is moderately cold and subhumid. The frost-free season lasts 90-115 days 
(Kolesnikov et al., 1973). This area is typically forested. 21 forest types were identified and described in the study area (Kolesnikov et al., 1973). These types of forests are identified based on the geographical-genetic approach in forest typology (Ivanova \& Zolotova, 2014). The forest type in genetic typology is the main classification unit and represents a stage of the forest formation process, which combines all stages of recovery succession over the life of at least one generation of a common tree species. When selecting a forest type, the following factors are taken into account: uniformity of habitats, uniformity in ecological regimes (moisture, temperature, and other factors), common composition of the stand, common direction of successions, and reforestation. Compliance with these requirements assumes that the selected forest types will have a similar level of stand productivity (Ivanova \& Zolotova, 2014). Thus the forest type of genetic typology differs significantly from the Association in Braun-Blanquet syntaxonomy (Westhoff \& van der Maarel, 1973). Genetic typology allows us to take into account and study forest dynamics. This is why this scientific field is most popular for classifying vegetation in the Ural Mountains and beyond (Fomin et al., 2017).

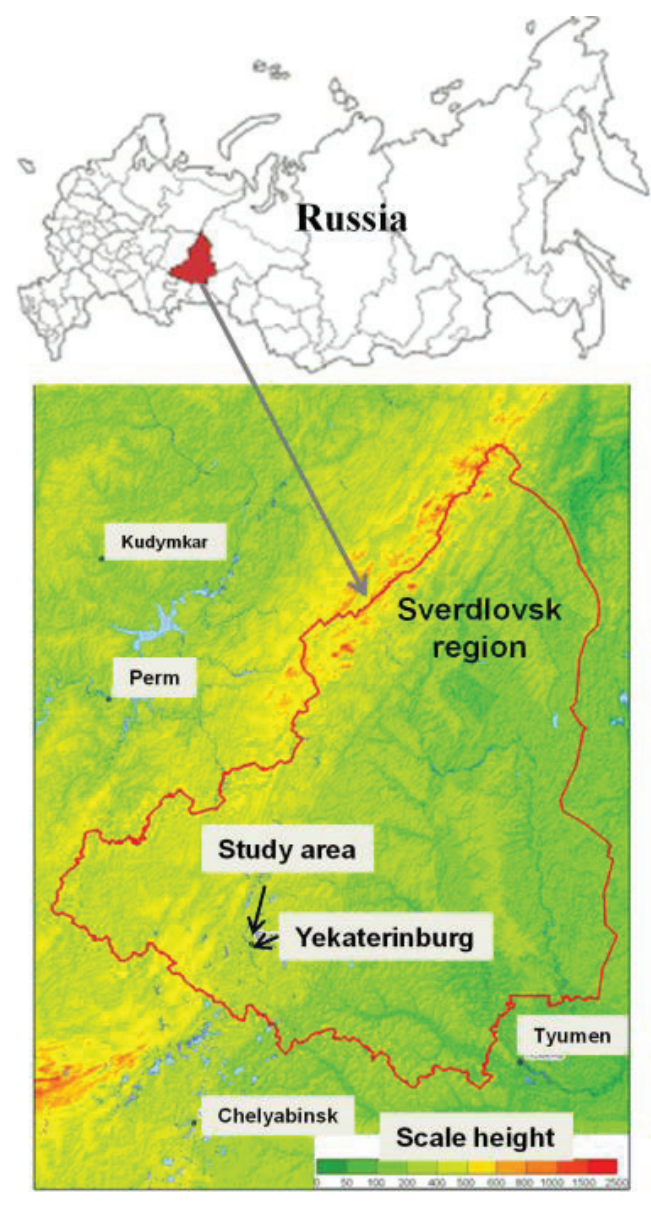

Figure 1. Study area

Pine forest types were primary forests in most habitats of the Zauralsky hilly piedmont province. Fir and spruce forests are common along rivers and in the interfluves. Larch and Linden are found everywhere, but do not form pure stands. Intensive forestry has been carried out here for more than 200 years. In addition to wood harvesting, forests are used for grazing livestock, picking berries and mushrooms. Forest fires are also a common impact. Reforestation after logging and forest fires occurs with the change of the edifier. Pine and spruce forests are replaced by birch and aspen forests. The change of the forest-forming tree species can be either short-term or long-term. At present, secondary birch and aspen forests are becoming more widespread. Nevertheless, small areas of forests close to the primary ones have been preserved and represent the most interesting object for research.

Within boundaries of the Zauralsky hilly piedmont province, a wide variety of soils exists due to terrain complexity and geological structure, mesoclimate and vegetation cover diversity. The main background of soil cover in this region includes mountain forest soils. The study area is characterized by brown mountain forest soils (Haplic Cambisols) and sod-podzolic soils (Umbric Albeluvisols). Peaty and peat boggy (Histic Gieysols) prevail among bog soils.

\subsection{Study designed, sampling and measurements}

To carry out the research, sample plots $(0.25$ hectares $)$ were laid in pine forests growing in habitats with different moisture regimes: insufficient, optimal (stable), and excessive. The research was conducted in 2010. Insufficient soil moisture regime is typical for the upper parts of the steep southern slopes. Brown mountain forest soils (Haplic Cambisols) with thickness of $15 \mathrm{~cm}$, in places up to $40 \mathrm{~cm}$, and a high content of crushed stone of the parent rock are common in these habitats. Soil moisture here mainly depends on weather conditions and varies greatly. Pine forests with Vaccinium vitis-idaea grow in these habitats (Fig. 2). According to the schemes of forest types developed for the Ural Mountains based on the principles of genetic forest typology, these forests are called cowberry pine forests (Kolesnikov et al., 1973). According to Braun-Blanquet syntaxonomy, these belong to the Vaccinio-Piceetea class, Dicrano-Pinion alliance (Westhoff \& van der Maarel, 1973). The pine forest studied is 160 years old. During this time, it was not exposed to logging and intense forest fires. The forests were little used for picking berries and mushrooms. The height of the stand is 24 meters, pine basal area is $44 \mathrm{~m}^{2} / \mathrm{ha}$, diameter is $36.5 \mathrm{~cm}$. 
The optimal (stable) soil moisture regime is typical for gentle mountain slopes with sod-podzolic soils (Umbric Albeluvisols). Soil profile thickness is about $90 \mathrm{~cm}$. A paleyellow podzolized horizon with a brown or grey tinge and 20-30 cm in thickness is common for soils. In these habitats, pine forests with well developed multispecies herbaceous layer are common, and they show features both of the Brachypodio Pinnati-Betuletea class and Vaccinio-Piceetea (Westhoff \& van der Maarel, 1973). According to the schemes of forest types developed for the Ural Mountains based on the principles of genetic forest typology, these forests are called multi-herb pine forests (Kolesnikov et al., 1973). The pine forest studied is 150 years old. During this time, it was not exposed to logging and intense forest fires. The height of the stand is 28.9 meters, pine basal area is $42.3 \mathrm{~m}^{2} /$ ha, diameter is $35.5 \mathrm{~cm}$. In addition to pine ( $P i$ nus sylvestris), the stand contains birch (Betula pubescens and B. pendula) and Siberian spruce (Picea obovata).

Habitats with excessive soil moisture are characterized by Histic Gieysols with profile thickness of more than $70 \mathrm{~cm}$. There are sphagnum tiers $10-15 \mathrm{~cm}$ in thickness and dark brown peat horizon with layers differed in color and density. In these habitats, pine forests with Eriophorum vaginatum, Chamaedaphne calyculata, Ledum palustre. They should be classified as the Vaccinietea uliginosi class. These forests have similarities to both of the Vaccinio-Piceetea class and the Oxycocco-Sphagneta class (Westhoff \& van der Maarel, 1973). According to the schemes of forest types developed for the Ural Mountains based on the principles of genetic forest typology, these forests are called pine forests with shrubs and sphagnum (Kolesnikov et al., 1973). The pine forest studied is 70 years old. During this time, it was not exposed to logging and intense forest fires. The studied pine forests are actively used for collecting cranberries. The stand is low-growing and sparse.

Comprehensive forest typological and soil studies were carried out based on generally accepted research methods (Ivanova, 2017). Overstorey and understorey layers was studied. Detailed comparative analysis of the tree stand, species diversity and species composition of the studied forest types were presented earlier (Ivanova, 2019, 2020; Zolotova \& Ivanova, 2015).

To determine the herb layer biomass (the herb layer included all non-woody plants and woody plants whose height did not exceed the herb height), 10-20 subplots $1 \times 1 \mathrm{~m}$ in size were laid on each sample plot. Their quantity depended on the vegetation cover mosaic. The study was carried in July 2010. Herb cover was determined by fractional counting method (Ivanova, 2017): a wooden frame $1 \times 1 \mathrm{~m}$ in size, divided into $0.1 \times 0.1 \mathrm{~m}$ boxes, was used in the research. To evaluate the species cover, each box was taken as $1 \%$. To determine the biomass of the herb in $1 \times 1 \mathrm{~m}$ plots, plants were cut at soil level, sorted by species, dried to absolutely dry condition at $105^{\circ} \mathrm{C}$ and weighed.

\subsection{Data analyses}

Data analysis is based on the One-way ANOVA and HSD test for multiple comparisons. In addition, we used the species abundance distributions as a new and promising meth-
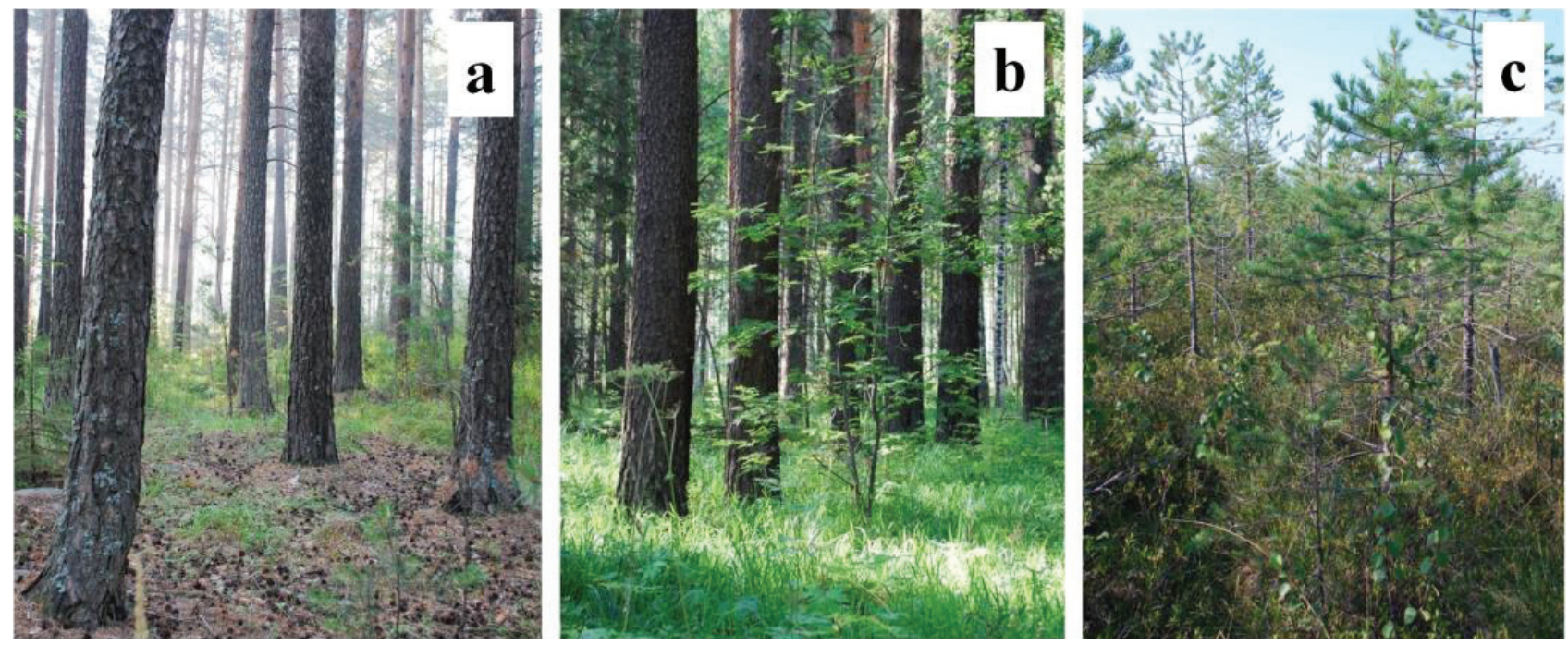

Figure 2. Research objects: a - insufficient soil moisture regime: pine forests with Vaccinium vitis-idaea on upper parts of the steep southern slopes (Cowberry pine forests), b - optimal (stable) soil moisture regime: pine forests with well developed multispecies herbaceous layer on gentle mountain slopes with thick soils (Multi-herb pine forests), c - excessive soil moisture: pine forests with Eriophorum vaginatum, Chamaedaphne calyculata, Ledum palustre (Pine forests with shrubs and sphagnum) 
od (Puzachenko, 2016; Guerin et al., 2017; Villa et al., 2019). Species abundance distributions for aboveground herb biomasss constructed as follows: all herb species are sorted in descending order of biomass, the ordinal number of the species in this series is the rank number (rank). Approximation was carried out by means of exponential and power functions in Excel.

\section{Results}

In all studied forest types, Pinus sylvestris L is a forest edificatory. Such accompanying species as Betula pubescens Ehrh., B. pendula Roth. can be found in the tree stand, and Larix sibirica Ledeb. Despite high similarity of the tree stand, the species composition of the herb layer of the studied forest communities varies dramatically (Table 1). Species richness in extreme (insufficient and excessive soil moisture regimes) and optimal (stable) soil moisture regime varies statistically significantly, and soil moisture is a statistically significant factor (Fig. 3, Table 2). Species richness sharply decreases with insufficient and excessive soil moisture, as the number of species capable to grow in extreme habitat is not high.

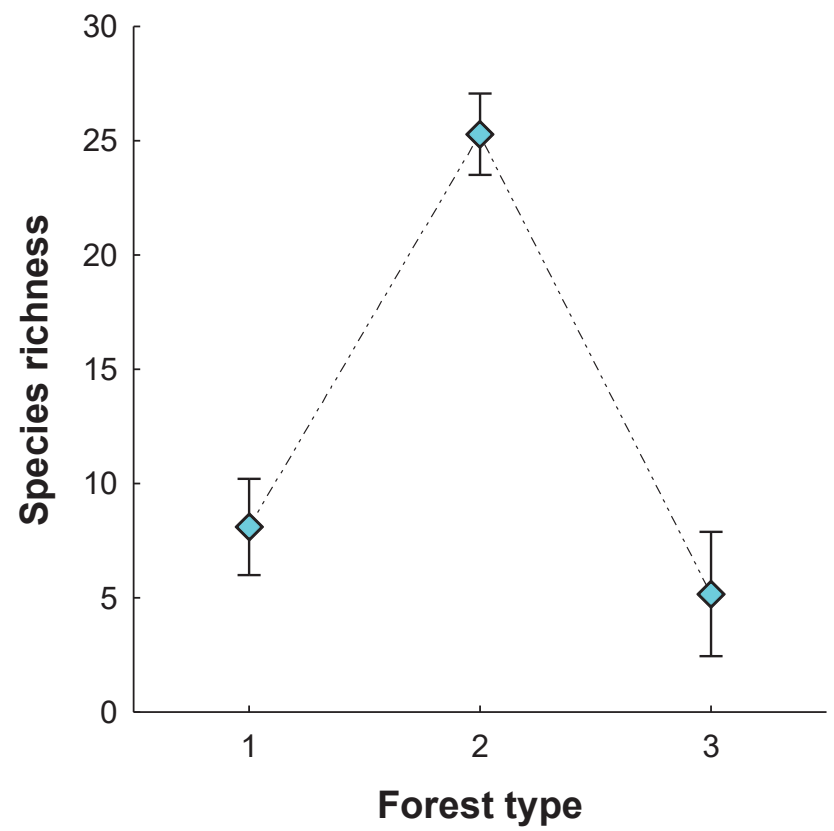

Figure 3. Species richness of the herb layer $\left(\right.$ per $\left.1 \mathrm{~m}^{2}\right)$ of three forest types: average value and 95\% interval; 1 - Insufficient soil moisture regime: Cowberry pine forest, 2 - Optimal (stable) soil moisture regime: Multi-herb pine forest, 3 - Excessive soil moisture: Pine forest with shrubs and sphagnum

Table 1. Diagnostic and dominant species of the herb layer in the studied Middle Ural forests

\begin{tabular}{|c|c|}
\hline Diagnostic species forest types & Dominant species forest type \\
\hline \multicolumn{2}{|c|}{$\begin{array}{l}\text { Insufficient soil moisture regime: pine forests with Vaccinium vitis-idaea on upper parts of the steep southern slopes (Cowberry } \\
\text { pine forests) }\end{array}$} \\
\hline Antennaria dioica (L.) Gaertn., Vaccinium vitis-idaea L. & Calamagrostis arundinacea (L.) Roth, Vaccinium vitis-idaea L. \\
\hline \multicolumn{2}{|c|}{$\begin{array}{l}\text { Optimal (stable) soil moisture regime: pine forests with well developed multispecies herbaceous layer on gentle mountain slope } \\
\text { with thick soils (Multi-herb pine forests), }\end{array}$} \\
\hline $\begin{array}{l}\text { Aegopodium podagraria L., Heracleum sibiricum L., } \\
\text { Lathyrus vernus (L.) Bernh., Viola mirabilis L. }\end{array}$ & $\begin{array}{l}\text { Calamagrostis arundinacea (L.) Roth, Brachypodium pinnatum } \\
\text { (L.) Beauv., Rubus saxatilis L. }\end{array}$ \\
\hline \multicolumn{2}{|c|}{$\begin{array}{c}\text { Excessive soil moisture: pine forests with Eriophorum vaginatum, Chamaedaphne calyculata, Ledum palustre (Pine forests with } \\
\text { shrubs and sphagnum) }\end{array}$} \\
\hline $\begin{array}{l}\text { Eriophorum vaginatum L., Chamaedaphne calyculata L., } \\
\text { Ledum palustre L. }\end{array}$ & $\begin{array}{l}\text { Eriophorum vaginatum L., Chamaedaphne calyculata L., Ledum } \\
\text { palustre L. }\end{array}$ \\
\hline
\end{tabular}


However, herb layer productivity is maintained sufficiently stable regardless of the moisture conditions. ANOVA showed no significant differences between pine forests growing under different soil moisture regimes $(\mathrm{F}(2.27)=0.98, \mathrm{p}=0.39)$ (Fig. 4)

Species abundance distributions for aboveground herb biomass for three forest types under different soil moisture regimes is shown in figures 5, 6, and 7. Exponential and power functions were used for approximation. Both functions produce satisfactory results, but there are peculiarities for different habitat. The largest number of species is registered in multi-herb pine forests at the optimal (stable) soil moisture regime (Fig. 6). The species abundance distributions are the most flattened. The exponential function showed better approximation. This indicates that the species abundance distribution corresponds to the theoretical law of Gibbs (or Motomura) (Whittaker, 1980). $\mathrm{R}^{2}$ makes 0.856 , the parameter value $\beta$ (power value) is 0.11 . It has been established that this distribution model is realized when the system state is linearly dependent on the resource (Shitikov et al., 2011). Regarding insufficient and excessive soil moisture regime, both exponential and power function are well suited to approximate species abundance distributions (Fig. 5 and 7). $\mathrm{R}^{2}$ is more than 0.9. When the exponential function was used for approximation, an increase in the parameter $\beta$ up to 0.51 was revealed for insufficient soil moisture regime (cowberry pine forests) (Fig. 3) and up to 0.93 for excessive soil moisture regime (pine forest with shrubs and sphagnum) (Fig. 5).

The approximation result obtained by means of the power function (Pareto distribution (Shitikov et al., 2011) showed that the parameter value $\beta$ (power value) increases from 1.72 (optimal (stable) soil moisture regime) to 2.92 for

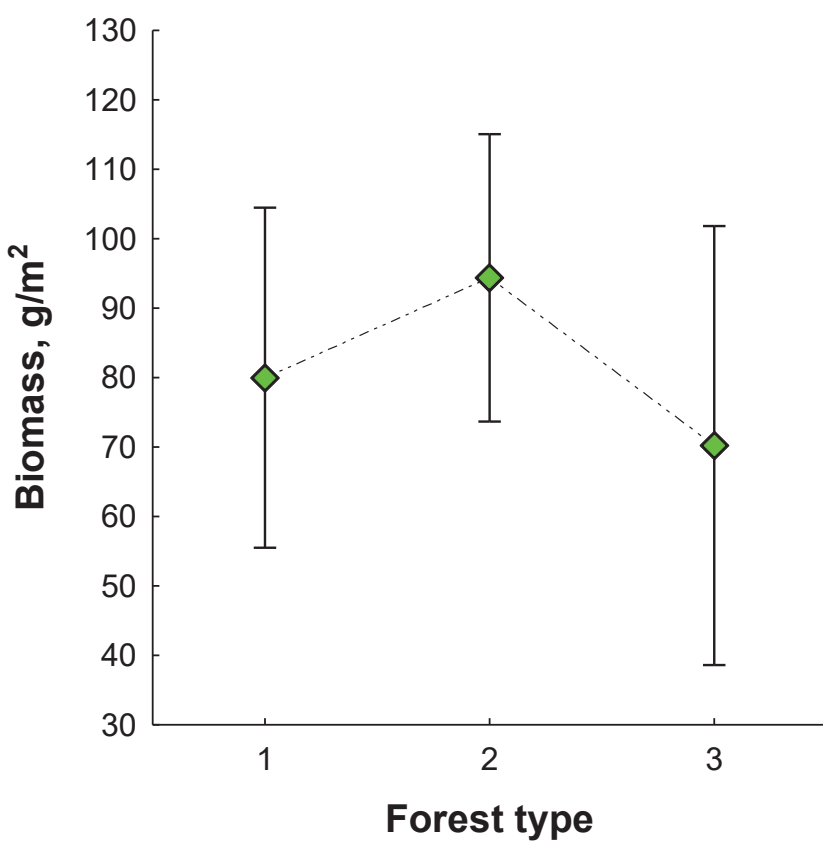

Figure 4. Aboveground biomass of the herb layer (in absolutely dry condition, $\mathrm{g} / \mathrm{m}^{2}$ ) of three forest types: average value and 95\% interval; 1 - Insufficient soil moisture regime: Cowberry pine forest, 2 - Optimal (stable) soil moisture regime: Multi-herb pine forest, 3 - Excessive soil moisture: Pine forest with shrubs and sphagnum

Table 2. HSD test results for three forest types in Middle Ural forests

\begin{tabular}{|c|c|c|c|}
\hline Soil moisture regime / forest type & Insufficient & $\begin{array}{l}\text { Optimal } \\
\text { (stable) }\end{array}$ & Excessive \\
\hline \multicolumn{4}{|c|}{ For species richness } \\
\hline Insufficient soil moisture regime / Cowberry pine forest & & $0.0001 *$ & 0.2058 \\
\hline Optimal (stable) soil moisture regime / Multi-herb pine forest & $0.0001 *$ & & $0.0001 *$ \\
\hline Pine forest with shrubs and sphagnum & 0.2058 & $0.0001 *$ & \\
\hline \multicolumn{4}{|c|}{ For aboveground biomass } \\
\hline Insufficient soil moisture regime / Cowberry shrub pine forest & & 0.633 & 0.871 \\
\hline Optimal (stable) soil moisture regime / Multi-herb pine forest & 0.633 & & 0.401 \\
\hline $\begin{array}{l}\text { Excessive soil moisture / Pine forest with shrubs and } \\
\text { sphagnum }\end{array}$ & 0.871 & 0.401 & \\
\hline
\end{tabular}

Note: $*$ - statistically significant differences at the significance level 0.05 

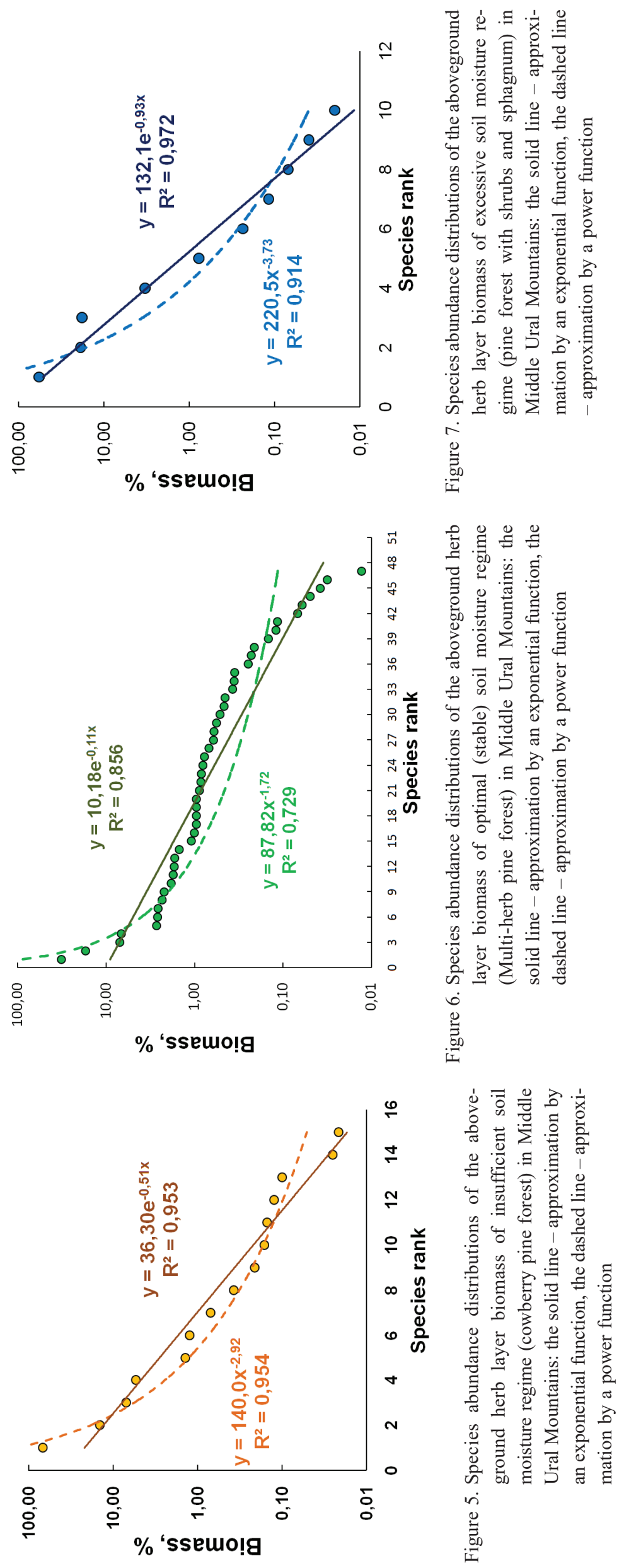
insufficient soil moisture regime (cowberry pine forests) and to 3.73 for excessive soil moisture regime (pine forests with shrubs and sphagnum). In addition, the increase of $\mathrm{R}^{2}$ from 0.73 for optimal (stable) soil moisture regime (multiherb pine forests) to 0.95 for insufficient soil moisture regime (cowberry pine forests) and to 0.91 for excessive soil moisture regime (pine forests with shrubs and sphagnum) can be considered a transition to logarithmic ecosystem species dependence on the resource. Thus, while maintaining the aboveground biomass, the increase of $\beta$ parameter of exponential and power aproximating functions can be considered an indicator of soil moisture factor on the ecosystem and a measure of its adaptation to insufficient and excessive soil moisture regime.

\section{Discussion}

The problems of biodiversity (Mirkin et al., 2014; Sannikov et al., 2017; Ivanova, 2019) and forest productivity (Usoltsev et al., 2011, 2019; Schepaschenko et al., 2017), ecology of individual species of woody plants (Kalashnikova \& Makhnev, 2013; Maiti et al., 2016; Sannikov et al., 2018), history of vegetation development (Panova \& Antipina, 2016), reforestation and stand formation (Tantsyrev \& Sannikov, 2008; Menshchikov et al., 2013; Fomin et al., 2015; Zalesova et al., 2019) have been actively discussed in the literature for the Ural Mountains, but our study on the adaptation of forest ecosystem vegetation to different moisture regimes is one of the first for taiga mountain forests in Russia. It has estimated the stability and trends of changing species composition and productivity when changing the moisture regime. The identification of the herb layer biomass stability in old-growth pine forests growing in sharply different habitats is an interesting and important result. It can be interpreted as an adaptation of the forest ecosystem to the studied factor. Less adapted species are replaced by more adapted ones, and the General aboveground biomass of the herb layer remains stable. In addition, identifying species diversity and herb layer biomass quantifying in the coniferous forests of the Ural Mountains can help to better understand how ecosystem services depend on soil moisture regime. For example, it is crucial to understand that reducing species diversity in adverse habitats will not necessarily lead to reduced stability and productivity. But the adapt ability has limits and it needs to be determined. It can be assumed that adaptation allows many other ecosystem functions to be preserved. It is of great importance, since the protection of soil and water resources is an important ecosystem service of the coniferous forests of the Ural Mountains. The ecosystem services for preserving moisture in case of insufficient soil moisture on steep mountain slopes are especially important. It is achieved by reducing the rate of snowmelt and water runoff. Under the same conditions, protection of the soil from erosion is of great importance (Lebedev, 2011). Forests in waterlogged habitats perform the function of preserving the quality of water resources (Lebedev, 2011).

It can also be assumed that the adaptation of the forest ecosystem is positively associated with climate-regulating functions, since the collapse of primary forests and their replacement with secondary communities inevitably leads to a decrease in it (Pavlov \& Bukvareva, 2007). The location of the Ural Mountains on the border of Europe and Asia makes them particularly sensitive to climate change (Kapralov et al., 2006) and it is important to be able to reliably assess the impact of it on mountain forests and their ecosystem services. Therefore, it is important to understand the mechanisms of adaptation and the limits of the forest ecosystem's resilience to various natural and anthropogenic factors. For this purpose, we tested (for the first time for mountain forests) species abundance distribution. This method is rarely used in forest ecology. However, the existing single attempts to use it proved to be effective for solving the tasks set (Cheng et al., 2011; Li-Xia et al., 2011; Yan et al., 2013). In our research, species abundance distribution also performed well and provided a number of new and important conclusions for sustainable forest management. Using species abundance distribution analysis, it was found that biomass is maintained by increasing of the dominant species contribution to the overall biomass and increasing of the approximation function graph slope. At the same time, the parameter $\beta$ of exponential and power approximating functions is increased and can be considered as an indicator of influencing on forest ecosystems and a measure of their adaptation to insufficient and excessive soil moisture. Thus, species abundance distributions can be used as universal, accurate, and intuitively comprehensible methods to measure the effects of determined forest ecosystem composition and functioning. Their advantage is also to provide an opportunity to compare forest communities that differ in both species richness, and species composition. In addition, this method may prove to be a useful tool to protect nature in the context of the analysis and assessment of species rarity in different habitats.

\section{Conclusion}

Thus, the features of the species richness and biomass of the herb layer were revealed for old-age coniferous forests growing under different soil moisture regimes. It has been established that species richness in extreme (insufficient and excessive soil moisture regime (Cowberry pine forest and Pine forest with shrubs and sphagnum) and optimal (stable) soil moisture regime (Multi-herb pine forest) were found to vary significantly, with soil moisture regime being a statistically significant factor. By contrast, herb layer 
biomass is maintained fairly stable regardless of the soil moisture regimes. ANOVA showed no significant differences between pine forests growing under different soil moisture regimes. It has been found that biomass is maintained by increasing of the dominant species contribution to the overall biomass and increasing of the approximation function graph slope. At the same time, the parameter $\beta$ of exponential and power approximating functions is increased and can be considered as an indicator of influencing on forest ecosystems and a measure of their adaptation to insufficient and excessive soil moisture. Thus, species abundance distributions can be used as method to measure the effects of factors that determine forest ecosystem composition and functioning.

\section{Acknowledgments}

The work was performed within the framework of the state task of the A.N. Zavaritsky Institute of Geology and Geochemistry of the Ural branch of the Russian Academy of Sciences (state registration no. AAAA-A18-118052590028-9) and as part of the state task of the Botanical garden of the Ural Branch of the Russian Academy of Sciences and National Natural Science Foundation of China, grant number 31971488 .

\section{References}

Aganina U.E. \& Tarkhanov S.N., 2016, Variability of biochemical indicators and adaptation of $\mathrm{f}$. (var.) sulfuranthera Kozubow forms of the pine (Pinus sylvestris L.) in the conditions of excess humidification. Izvestia of the Samara Scientific Center of the Russian Academy of Sciences 18(2-1): 10-14.

Alamgir M., Pert P.L. \& Turton S.M., 2014, A review of ecosystem services research in Australia reveals a gap in integrating climate change and impacts on ecosystem services. International Journal of Biodiversity Science, Ecosystem Services \& Management 10: 112-127. doi: 10.1080/21513732.2014.919961

Astamirova M.A.-M., Umarov M.U. \& Taysumov M.A., 2016, Anatomical and physiological adaptations of cryophilic plants of central and eastern Main Caucasus Ridge. The Bulletin of KrasGAU 11: 114-122.

Bouchard M., Aquilué N., Périé C. \& Lambert M-C., 2019, Tree species persistence under warming conditions: A key driver of forest response to climate change. Forest Ecology and Management 442: 96-104. doi: 10.1016/j.foreco.2019.03.040.

Bucher S.F., Feiler R., Buchner O., Neuner G., Rosbakh S., Leiterer M. \& Römermann C., 2019, Temporal and spatial trade-offs between resistance and performance traits in herbaceous plant species. Environmental and Experimental Botany 157: 187-196. doi: 10.1016/j.envexpbot.2018.10.015.

Calder R.S.D., Shi C., Mason S.A., Olander L.P. \& Borsuk M.E., 2019, Forecasting ecosystem services to guide coastal wetland rehabilitation decisions. Ecosystem Services 39: 101007. doi:10.1016/j.ecoser.2019.101007.

Cheng J., Mi, X., Ma K. \& Zhang J., 2011, Responses of species-abundance distribution to varying sampling scales in a subtropical broad-leaved forest. Biodiversity Science 19: 168-177. doi:10.3724/sp.j.1003.2011.10107.

Courbier S. \& Pierik R., 2019, Canopy Light Quality Modulates Stress Responses in Plants. iScience 22: 441452. doi:10.1016/j.isci.2019.11.035.

Ferreira W.N., Lacerda C.F., Costa R.C. \& Medeiros Filho S., 2015, Effect of water stress on seedling growth in two species with different abundances: the importance of Stress Resistance Syndrome in seasonally dry tropical forest. Acta Bot. Bras. 29(3): 375-382. doi: 10.1590/0102-33062014abb0045.

Fisher B., Turner R.K. \& Morling P., 2009, Defining and classifying ecosystem services for decision making. Ecol. Econ. 68: 643-653. doi:10.1016/j. ecolecon.2008.09.014.

Fomin V.V., Zalesov S.V. \& Magasumova A.G., 2015, Methods of tree stands density assessment of agricultural land reforestation with the use of satellite images with high spatial resolution. Agrarian Bulletin of the Urals 1: 25-29.

Fomin V.V., Zalesov S.V., Popov A.S. \& Mikhailovich A.P., 2017, Historical avenues of research in Russian forest typology: ecological, phytocoenotic, genetic, and dynamic classifications. Canadian Journal of Forest Research 47: 849-860. doi: 10.1139/cjfr-2017-0011.

Franklin K.A. \& Wigge P.A., 2014, Temperature and Plant Development. John Wiley \& Sons Inc., Oxford, UK, 250 pp. doi:10.1002/9781118308240.

Galicia L. \& Zarco-Arista A.E., 2014, Multiple ecosystem services, possible trade-offs and synergies in a temperate forest ecosystem in Mexico: a revie. International Journal of Biodiversity Science, Ecosystem Services \& Management 10: 275-288. doi:10.1080/21513732.2014 973907.

Guerin G.R. \& Lowe A.J., 2013, Multi-species distribution modelling highlights the Adelaide Geosyncline, South Australia, as an important continental-scale arid-zone refugium. Austral Ecology 38: 427-435.

Guerin G.R., Sparrow B., Tokmakoff A., Smyth A., Leitch E., Baruch Z. \& Lowe A.J., 2017, Opportunities for Integrated Ecological Analysis across Inland Australia with Standardised Data from Ausplots Rangelands. PLoS ONE 12(1): e0170137. doi: 10.1371/journal. pone. 0170137 . 
Habarova E.P., Feklistov P.A. \& Kosheleva A.E., 2015, Contents of mineral elements in the dying off needles of scotch pine on drained areas. Forestry Bulletin 19(2): 15-20.

Halofsky J.E., Andrews-Key S.A., Edwards J.E., Johnston M.H., Nelson H.W., Peterson D.L., Schmitt K.M., Swanston C.W. \& Williamson T.B., 2018, Adapting forest management to climate change: The state of science and applications in Canada and the United States. Forest Ecology and Management 421: 84-97. doi: 10.1016/j.foreco.2018.02.037.

Haunschild R., Bornmann L. \& Marx W., 2016, Climate Change Research in View of Bibliometrics. PLoS ONE 11(7): e0160393. doi:10.1371/journal.pone.0160393

Hänninen H., 2016, Boreal and Temperate Trees in a Changing Climate: Modelling the Ecophysiology of Seasonality. Springer, Dordrecht, 342 pp. doi:10.1007/978-94017-7549.

Hölting L., Beckmann M., Volk M. \& Cord A.F., 2019, Multifunctionality assessments - More than assessing multiple ecosystem functions and services? A quantitative literature review. Ecological Indicators 103: 226235. doi:10.1016/j.ecolind.2019.04.009.

Ivanova N., 2017, Research Methods of Timber-Yielding Plants (in the Example of Boreal Forests), [in:] M.N. Heya, R. Maiti, R.F. Pournavab, A. Carrillo-Parra (eds), Biology, Productivity and Bioenergy of Timber-Yielding Plants: An Experimental Technology. Springer, Cham, pp. 121-137. doi: 10.1007/978-3-319-6179852.

Ivanova N.S., 2019, Biodiversity of Old-growth Coniferous Forests in the Ural Mountains. International Journal of Bio-resource and Stress Management 10: 251-256. doi:10.23910/ijbsm/2019.10.3.1985.

Ivanova N.S., 2020, Impact of Climate Changes, Timber Harvesting, and Fires on Boreal Forests (Example of the Ural Mountains, Russia), [in:] R. Maiti, H.G. Rodríguez, Ch.A. Kumari, D. Mandal (eds), Sustainable Bioresource Management: Climate Change Mitigation and Natural Resource Conservation. Apple Academic Press, CRC Press, New York, pp. 29-52. doi:10.1201/9780429284229-4.

Ivanova N.S. \& Zolotova E.S., 2014, Development of Forest Typology in Russia. International Journal of Bio-resource and Stress Management 5: 298-303. doi:10.5958/0976-4038.2014.00572.7.

Kalashnikova I.V. \& Makhnev A.K., 2013, Specific features of root system structure in the main forest-forming species of the Middle Urals growing on cinder dumps. Russian Journal of Ecology 44: 375-380. doi:10.1134/ S106741361305007X.

Kamlun K.U. \& Arndt R.B., 2019, Expert-Based Approach on Mapping Ecosystem Services Potential Supply Incircling a Protected Areas by Integrating Matrix Mod- el Assessment. Journal of Physics: Conference Series 1358: 012032. doi:10.1088/1742-6596/1358/1/012032.

Kapralov D.S., Shiyatov S.G., Moiseev P.A. \& Fomin V.V., 2006, Changes in the composition, structure, and altitudinal distribution of low forests at the upper limit of their growth in the North Ural Mountains. Russian Journal of Ecosystem Ecology 37: 367-372. doi:10.1134/S1067413606060014.

Kellomäki S., 2016, Managing Boreal Forests in the Context of Climate Change: Impacts, Adaptation and Climate Change Mitigation. CRC Press, 365 pp. doi:10.1201/9781315166063.

Kolesnikov B.P., Zubareva R.S. \& Smolonogov E.P., 1973, Lesorastitelnye usloviya i tipy lesov Sverdlovskoj oblasti. Prakticheskoe rukovodstvo [Forest conditions and forest types of the Sverdlovsk region: The practical guide]. UNTS of Academy of Science of the USSR, Sverdlovsk, $176 \mathrm{pp}$.

Landuyt D., Broekx S., D’hondt R., Engelen G., Aertsens J., Goethals P.L.M., 2013, A review of Bayesian belief networks in ecosystem service modeling. Environ. Model. Software 46: 1-11. doi.org/10.1016/j.envsoft.2013.03.011.

Lebedev Yu.V., 2011, Assessment of forest ecosystems in the economy of nature management. Ural branch of the Russian Academy of Sciences, Yekaterinburg, 574 pp. Legoshchina O.M., Tsandekova O.L. \& Kolmogorova E.Yu., 2019, Structural restructing of the sheet apparatus Betula Pendula Roth on the dumps of the coal mining industry. Izvestia of Samara Scientific Center of the Russian Academy of Sciences 2-2: 199-203.

Li-Xia G.A.O., Run-Cheng B.I. \& Ming, Y.A.N., 2011, Species abundance distribution patterns of Pinus tabulaeformis forest in Huoshan Mountain of Shanxi Province, China. Journal of Plant Ecology 35: 1256-1270. doi:10.3724/sp.j.1258.2011.01256.

Maiti R., Rodriguez H.G. \& Ivanova N.S., 2016, Autoecology and Ecophysiology of Woody Shrubs and Trees: Concepts and Applications. John Wiley \& Sons, New Jersey, USA, $352 \mathrm{pp}$.

Mengist W., Soromessa T. \& Legese G., 2019, Ecosystem Services Research in Mountainous Regions: A Systematic Literature Review on Current Knowledge and Research Gaps. Science of The Total Environment 702: 134581. doi:10.1016/j.scitotenv.2019.134581.

Menshchikov S.L., Baranovskii V.V. \& Kuzmina N.A., 2013, Density of Scots pine undergrowth after ground fires in a zone of industrial air pollution. Russian Journal of Ecology 44: 367-370. doi:10.1134/ S106741361305010X.

Millennium Ecosystem Assessment, 2005, Ecosystems and human well-being: a framework for assessment. Island Press, Washington, 155 pp. https:/www.millenniumas- 
sessment.org/documents/document.356.aspx.pdf [Accessed: 3 April 2020].

Mirkin B.M., Martynenko V.B. \& Naumova L.G., 2014, Assessment of vegetation $\beta$-diversity on the basis of syntaxonomy. Russian Journal of Ecology 45: 103-106. doi:10.1134/S1067413614020040.

Montwé D., Isaac-Renton, M., Hamann, A., Spiecker H., 2018, Cold adaptation recorded in tree rings highlights risks associated with climate change and assisted migration. Nature Communications 9(1): 1574. doi:10.1038/ s41467-018-04039-5.

Muller J.J., Nagel L.M. \& Palik B.J., 2019, Forest adaptation strategies aimed at climate change: Assessing the performance of future climate-adapted tree species in a northern Minnesota pine ecosystem. Forest Ecology and Management 451: 117539. doi: 10.1016/j.foreco.2019.117539.

Mumba M., Kutegeka S., Nakangu B., Munang R. \& Sebukeera C., 2016, Ecosystem-based Adaptation (EbA) of African Mountain Ecosystems: Experiences from Mount Elgon, Uganda, [in:] N. Salzmann, C. Huggel, S.U. Nussbaumer, G. Ziervogel (eds), Climate Change Adaptation Strategies - An Upstream-downstream Perspective. Springer International Publishing Switzerland, pp. 121-140. doi: 10.1007/978-3-31940773-9 7.

Murray D.L., Peers M. J.L., Majchrzak Y.N., Wehtje M., Ferreira C. \& Pickles R.S.A., 2017, Continental divide: Predicting climate-mediated fragmentation and biodiversity loss in the boreal forest. PLoS ONE 12(5): e0176706. doi: 10.1371/journal.pone.0176706.

Panova N.K. \& Antipina T.G., 2016, Late Glacial and Holocene environmental history on the eastern slope of the Middle Ural mountains, Russia. Quaternary International 420: 76-89. doi:10.1016/j.quaint.2015.10.035.

Paraskevopulo M.F., Suntsova L.N. \& Inshakov E.M., 2017, Studying of pigmentary structure of some species of wood plants in the conditions of technogenic pollution of the city of Krasnoyarsk. Conifers of the boreal area XXXV(1-2): 54-59.

Parrotta J., Yeo-Chang Y. \& Camacho L.D., 2016, Traditional knowledge for sustainable forest management and provision of ecosystem services. International Journal of Biodiversity Science, Ecosystem Services \& Management 12: 1-4. doi:10.1080/21513732.2016. 1169580.

Pavlov D.S. \& Bukvareva E.N., 2007, Biodiversity and life support of humankind. Her. Russ. Acad. Sci. 77: 550562. doi:10.1134/S1019331607060020.

Polle A., Chen S.L., Eckert C. \& Harfouche A., 2018, Engineering Drought Resistance in Forest Trees. Front. Plant Sci. 9: 1875. doi: 10.3389/fpls.2018.01875

Puzachenko Yu.G., 2016, Rank distributions in ecology and nonextensive statistical mechanics. Archives of Zoolog- ical Museum of Lomonosov Moscow State University 54: 42-71.

Ramakrishna A. \& Gill S.S., 2018, Metabolic Adaptations in Plants During Abiotic Stress. CRC Press, Boca Raton, $420 \mathrm{pp}$.

Safina G.R. \& Golosov V.N., 2018, The effect of climate change on the annual flow distribution of small rivers in the southern half of the European territory of Russia. Uchenye Zapiski Kazanskogo Universiteta. Seriya Estestvennye Nauki 160(1): 111-125.

Sannikov S.N., Petrova I.V., Sannikova N.S., Kochybei A.A. \& Sannikov D.S., 2017, Divergence of biogeocenoses within pine forest types. Russian Journal of Ecology 48: 340-349. doi:10.1134/S1067413617040142.

Sannikov S.N., Tantsyrev N.V. \& Petrova I.V., 2018, Invasion of Siberian pine populations in mountain tundra in the Northern Urals. Contemporary Problems of Ecology 11: 396-405. doi:10.1134/S1995425518040078.

Schepaschenko D., Shvidenko A., See L., McCallum I., Fritz S., Kraxner F., Obersteiner M., Usoltsev V., Lakyda P., Vasylyshyn R., Lakyda I., Luo Y. \& Myklush Y., 2017, A dataset of forest biomass structure for Eurasia. Scientific data 4: 170070. doi:10.1038/sdata.2017.70

Shaw M.R., Pendleton L., Cameron D.R., Morris B., Bachelet D., Klausmeyer K., MacKenzie J., Conklin D.R., Bratman G.N. \& Lenihan J., 2011, The impact of climate change on California's ecosystem services. Climatic Change 109: 465-484. doi:10.1007/s10584011-0313-4.

Shimalina N.D., Antonova E.V. \& Pozolotina V.N., 2019, Genetic polymorphism of Plantago major populations from the radioactive and chemical polluted areas. Environmental Pollution 257: 113607. doi: 10.1016/j.envpol.2019.113607.

Shitikov V.K., Zinchenko T.D. \& Rozenberg G.S., 2011, Macroecology of river communities: concepts, methods, models. Cassandra, Togliatti, 255 pp.

Soares J.C., Santos C.S., Carvalho S.M.P., Pintado M.M. \& Vasconcelos M.W., 2019, Preserving the nutritional quality of crop plants under a changing climate: importance and strategies. Plant and Soil 443: 1-26. doi:10.1007/s11104-019-04229-0.

Straub D. \& Grêt-Regamey A., 2006, A Bayesian probabilistic framework for avalanche modelling based on observations. Cold Reg. Sci. Technol. 46: 192-203. doi:1-0.1016/j.coldregions.2006.08.024.

Tantsyrev N.V. \& Sannikov S.N., 2008, Dynamics of environmental factors and Siberian stone pine regeneration in burned-out and clear-cut forest areas in the Urals. Russian Journal of Ecology 39: 140-144. doi:10.1134/ S1067413608020112.

Usoltsev V.A., Piernik A., Osmirko A.A., Tsepordey I.S., Chasovskikh V.P. \& Zukow W., 2019, Forest stand biomass of Picea spp.: an additive model that may be 
related to climate and civilisational changes. Bulletin of Geography. Socio-economic Series 45: 133-147. doi:10.2478/bog-2019-0029.

Usoltsev V.A., Voronov M.P. \& Chasovskikh V.P., 2011, Net primary production of Ural forests: methods and results of automated estimating. Russian Journal of Ecology 42: 362-370. doi:10.1134/S1067413611050122.

Villa P.M., Martins S.V., Rodrigues A.C., Safar N.V.H., Bonilla M.A.C. \& Ali A., 2019, Testing species abundance distribution models in tropical forest successions: Implications for fine-scale passive restoration. Ecological Engineering 135: 28-35. doi: 10.1016/j.ecoleng.2019.05.015.

Werners S.E., Szalai S., Zingstra H., Köpataki E., Beckmann A., Bos E., Civic K., Hlasny T., Hulea O., Jurek M., Koch O., Kondor A.C., Kovbasko A., Lakatos A., Lambert S., Peters R., Trombik J., van de Velde I., Zsuffa I., 2016, Climate Change Adaptation in the Carpathian Mountain Region, [in:] N. Salzmann, C. Huggel, S.U. Nussbaumer, G. Ziervogel (eds), Climate Change Adaptation Strategies - An Upstream-down- stream Perspective. Springer International Publishing Switzerland, pp. 79-99. doi: 10.1007/978-3-319-407739 5.

Westhoff V. \& van der Maarel E., 1973, The Braun-B1anquet approach. Handbook of Vegetation Science 5: 617-726.

Whittaker R., 1980, Communities and Ecosystems. Progress, Moscow, 327 pp.

Yan Y., Chun-Yu Z. \& Xiu-Hai Z., 2013, Species-abundance distribution patterns at different successional stages of conifer and broad-leaved mixed forest communities in Changbai Mountains, China. Journal of Plant Ecology 36: 923-934. doi:10.3724/sp.j.1258.2012.00923.

Zalesova E.S., Anan'ev E.M., Osipenko A.E., Shubin D.A. \& Terekhov G.G., 2019, Planting density effect on artificial pine stands stability. Forestry Bulletin 23: 22-27. doi:10.18698/2542-1468-2019-1-22-27.

Zolotova E.S. \& Ivanova N.S., 2015, Using D.N. Tsyganov's scales for analysis ecological space of forest types of Middle Urals. Fundamental Research 2: 5114-5119. 